\title{
Analysis of Business Organisational Change in Regional Business Enterprises: Case Study on Regional Company Services and Tourism in West Java Indonesia
}

\author{
Sam'un Jaja Raharja and Iriana Srikandiati* \\ Department of Business Administration Universitas Padjadjarn \\ Regional Training and Education Agency West Java Province \\ harja_63@yahoo.com,s.raharja2017@unpad.ac.id \\ srikandiati@yahoo.com
}

\begin{abstract}
The change in business organisation and organisational change are fundamental changes in a business activity to overcome its external environmental challenges. This study aims to analyse business organisational changes through case studies on the Regional Company Service and Tourism in West Java to establish the unfolding processes observed during an organisational change.

This study employs a research method that aims to generate findings towards understanding. Based on the characteristics of the research objectives, the appropriate form of qualitative research is a case study. Data were collected through interviews and literature studies.

Successful business organisational changes are closely tied to six factors, namely, leadership roles, communication strategies, stakeholder management, motivation, development of change interventions and management of the transition of stakeholders' personal attitudes. The six factors are closely related, and they sustain one another.

The research findings indicate the slow process change a business organisation has created primarily because of the less optimal process in which it manages people's issues, and secondly because the established process of change is not associated with the six success factors of business organisational change enumerated above.

The analysis indicates that the six factors mutually related to one another are processed by an iterative flow. The interrelationship among these iterative factors is not expressed in the Hayes generic model. The concept of interrelationship among factors serves as a model of change in a company owned by the Regional Government.
\end{abstract}

Keywords: business organisational change, regional business enterprises, people's issues, six-factor change, iterative flow

\section{Introduction}

Good Corporate Governance (GCG) stipulates that every company should apply the following GCG principles: transparency, accountability, responsibility, independence and fairness and equality, on every business aspect and company rank. The GCG General Guidelines place the Annual General Meeting of Shareholders, Board of Commissioners and Board of Directors as corporate organs crucial to GCG implementation (2006).

In line with this context, the West Java Provincial Government implements the policy to execute GCG to the Regional Government Owned Enterprise or Badan Usaha Milik Daerah (BUMD) through efforts to change the form of a legal entity, from Regional Company or Perusahaan Daerah $(P D)$ to Limited Liability Company or Perseroan

Received (July 15, 2017), Review Result (November 17, 2017), Accepted (November 18, 2017) 
Terbatas $(P T)$. One of the changes is accomplished in the Regional Company Services and Tourism or Perusahaan Daerah Jasa Kepariwisataan (PD Jawi). PD Jawi is a company owned by the Regional Government in the form of $P D$.

Kotter (1995) states that the goal of organisational change is nearly the same, that is, to make fundamental changes in the processes in which business activities can be controlled to overcome external environmental challenges. The results showed extremely few successful changes, some not working at all. Referring to Kotter, the success of change is determined through a series of specific stages and requires a specific period. Changes by increasing speed and skipping steps will not generate satisfactory results. Similarly, a onephase critical error can cause devastating effects, slowdown the momentum and negate previously elusive results. Cases occurring in organisational changes PD Jawi are slow allegedly due to the lack of good organisational change processes.

\section{Literature Review}

Jones (2010) argued that organisational goals are defined as finding new ways or improving old ways in utilising organisational resources and capabilities to enhance an organisation's ability to create values and revenue for stakeholders. Furthermore, Jones (2010) added the existing two types of change, namely, evolutionary and revolutionary changes.

Evolutionary change is defined as gradual and incremental change, with only limited focus. Evolutionary changes are constantly attempting to change, adapt and adjust structure and strategy (incrementally) to accommodate changes in the environment. Conversely, revolutionary changes involve speedy attempts in finding new ways to enhance the effectiveness of organisations. Revolutionary change is rapid and dramatic with considerable focus. The result is a radical shift in doing something and achieving a new goal or a new structure.

Based on both types of change, Jones (2010) further suggested several main instruments existing in each type. The main instruments of this type of evolutionary change are sociotechnical systems theory, total quality management and flexible workers and work teams. The instruments of revolutionary change types are re-engineering, restructuring and innovation (Jones, 2010).

Meanwhile, Lewin proposed a theory of organisational change called force-field theory. Lewin (1947) points out that 'A successful change includes therefore three aspects: unfreezing (if necessary) the present level, moving to the new level, and freezing the group life on the new level.' Lewin's third step is known as Lewin's three-step model of change (Jones, 2010; Hayes, 2010).

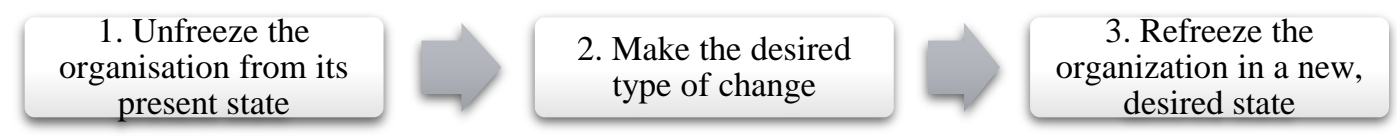

Figure 1. Three Steps of the Kurt Lewin Change Process (1)

Source: Jones, R. Gareth. Organizational Theory, Design, and Change, Sixth Edition. New Jersey: Pearson Education, Inc. Prentice Hall (2010), p. 311.

UNFREEZE MOVE $\quad$ REFREEZE

Figure 2. Three Steps of the Kurt Lewin Change Process (2)

Source: Hayes, John. 2010. The Theory and Practice of Change Management, Third Edition. New York: Palgrave Macmillan (2010), p. 29. 
Furthermore, Lewin divided power structure into two fields, namely, driving and restraining forces. According to Hayes (2010) and Jones (2010), the concept of the two fields of Lewin strength is illustrated in Figure 3 as follows:
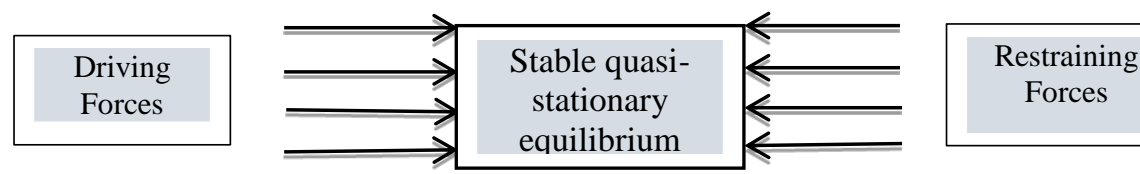

Figure 3. Katch Lewin's Force Field (A Force Field)

Source: Hayes, John. 2010. The Theory and Practice of Change Management, Third Edition. New York: Palgrave Macmillan (2010), p. xx.

By contrast to Lewin, Kotter developed theory of guiding change (leading change). Kotter (1995) suggests the following eight factors causing organisational change failure: (1) lack of a sense of urgency, (2) insufficient strength to guide coalition, (3) inadequacy of vision, (4) lack of communication for achievement of vision, (5) lack of attempt to remove obstacles to the achievement of vision, (6) lack of systematic planning and design to achieve short-term success, (7) too early announcement of the success of change, (8) detachment of change to corporate culture.

Based on his research, Kotter (1996) formulated eight steps to manage change, namely, (1) establishing a sense of urgency; (2) forming a powerful guiding coalition; (3) creating a new vision; (4) communicating; (5) empowering people; (6) planning, creating and rewarding short-term victories; (7) consolidating, consolidating improvements, reevaluating changes and making necessary adjustments; (8) reinforcing changes between new behaviours and organisational aspects.

Substantially, theory of guiding Kotter change is in line with Lewin's field strength theory. Kotter's eight steps elaborate the three stages of Lewin's change. This process is in line with Kotter's (1996) explanation of the eight steps to guide change. The first phase, which includes the first four steps, is a transformation process that dilutes the ice. The second stage, comprising the fifth to the seventh steps, is the process of introducing new practices. The third stage, the eighth step, is the process of 'solidifying' changes to the organisational culture and making it stick.

Continuing his theory, Kotter with Cohen (2002) refined the eight steps of guiding change to (1) increase urgency, characterised by individual conversations on changing needs; (2) build the guiding team, which sufficiently guides change and starts work together; (3) obtain the vision right, that is, the guiding team can develop a genuine vision and strategy for change effort; (4) communicate for buy-in, which characterises the entry of people into a process; (5) empower action, characterised by other people who can act and act to realize a vision; (6) create short-term wins, characterised by the majority of people filling in a determined vision, with only a few resistant to change; (7) not letting up, characterised by various waves of people's efforts to achieve a vision of change and (8) make changes stick, characterised by continuation of new behaviour.

In the next stage, Kotter (2012) refined his theory into the eight accelerators of change as follows: (1) create a sense of urgency around a single opportunity; (2) build and maintain a guiding coalition; (3) formulate a strategy; (5) accelerate movement towards a vision, with the opportunity network removing the barriers; (6) celebrate visible, significant shortterm wins; (7) never let up by continuing to learn from experience and not declaring victory too soon; and (8) institutionalise strategic changes in the culture.

In principle, the eight steps of acceleration change are not significantly different from the steps in theory of Kotter Leading Change or the eight steps in Kotter \& Cohen's Heart of Change. 
The conceptual difference between the eight steps of the previous change with the eightstep 'accelerator' lies in three aspects. (1) Step change is frequently used rigidly, definitely and sequentially; whereas the accelerator has the same functions and ways. (2) Step change is commonly driven by few or adequately strong core groups, whereas the accelerator is driven by as many parties as possible. (3) Step change is designed to function in a traditional hierarchy, whereas the accelerator requires the flexibility and agility of an existing network.

The success or failure of a change initiative involves not only initiating, planning, monitoring, implementing and evaluating projects; it also involves preparing for organisational change, ensuring stakeholders engagement and appealing to others to support the change, before, during and after execution. In this connection, Egan (in Hayes, 2010) stated the following: 'The management of change is not about planning or action but about achieving results-system-enhancing outcomes such as innovations realized, problems of organisation-enhancing behaviours put in place.'

In Egan's opinion, managing change is not a process of planning or acting but rather the achievement of system benefits in the form of innovation, effective management of issues, development of employment opportunities or achievement of behaviours corresponding to the organisation's expectations.

In Egan's statement, two existing terms have different meanings, namely, 'organisational change' and 'change management.' Creasey (2007) explained the difference between the term as follows:

It is not enough to merely prescribe 'the change' and expert it to happening change within an organization takes a hard work and structure around what must actually take place to make the change happen. To begin, let's look at the formal definitions of project management and change management - two disciplines required to bring a change to life. These are commonly accepted definitions that help us begin to think about these two distinct but intertwined disciplines.

Referring to Creasey's opinion, change does not automatically occur, as it requires hard work, as well as is structured and in place. To cause change in her life, Creasey revealed two required key disciplines, namely, project and change management. Creasey (2007) further elaborated his opinion as follows:

It can sometimes be hard to separate out 'the change', project management, and change management. In practice, these three components are interdependent in order to deliver a positive outcome to the organization. However, there is value in separating out the components. First, thinking about the three components separately makes it easier to define and help the others understand these distinct elements. Second, separating out these three components is a solid first step when troubleshooting on a particular project that may not be moving ahead as expected. For instance, are our challenges coming from issues around designing 'the change'? Are the issues related to the 'technical' steps, activities or resources (project management)? Or are concerns coming from how individuals are accepting or resisting the change (change management)?

Both project management and change management support moving on an organization from a current state (the things that are done today), through a transition state to a desire future state (the new processes, systems, organization structures or jobs role defined by 'the change'). Project management focuses on the tasks to achieve the project requirements. Change management focuses on the people impacted by the change. 
Project and change management are two distinct disciplines. However, they are intertwined and integrated with each other in practice. Steps and activities move simultaneously, similar to a work team that moves from one condition to another desired condition. If project management focuses on a series of jobs to achieve the 'technical' side of the project, whereas, change management focuses on people affected by the change in the 'people's' side.

\section{Methodology}

The problem requiring analysis in this study is organisational change, a process by which an organisation moves from certain to expected state in the future.

This study aims to analyse the process of business organisational change in PD Jawi to address the question of how the process of organisational change PD Jawi occurs. The study is conducted using qualitative research method with a case study on PD Jawi. Qualitative methods are defined by Strauss and Corbin (1990) as follows:

Any kind of research that produces the notes at the mean of statistical procedures or other means of quantifications. While Hoepfl (in Golafshani, 2003) states: 'Unlike quantitative researchers who seek causal determination, prediction, and generalization of findings, qualitative researchers seek instead illumination, understanding, and extrapolation to similar situation.'

Based on some of the above definitions, qualitative research produces findings without utilising statistical procedures but generates insightful research findings. Despite its relation to an appropriate form of qualitative research, Turner (in Locke, 2001) argues the following:

Similarly, across different research practice communities, researchers may share much in terms of their general methodological procedures. Indeed, the particular constraints created by all qualitative work, such as the need to collect a data set, to fracture it for manipulation, somehow to label and re-order the fracture elements, and so on, mean that the overall shape of qualitative data analysis will be quite similar.

Based on Turner's opinion, despite the nearly identical results of qualitative research, its application is quite different. Based on the characteristics of the research objectives, case studies are a qualitative form of research appropriately applicable to this study.

The case study method in this study based on the specific character of the case study method application is affirmed. According to Yin (2003),

A case study is an empirical inquiry that investigates a contemporary phenomenon within its real-life context, especially when the boundaries between object of study and context are not clearly evident. It copes with the technically distinctive situation in which there will be many more variables of interest than data points, and as one result relies on multiple sources of evidence, with data needing to converge in a triangulating fashion, and as another result benefits from the prior development of theoretical propositions to guide data collection and analysis.

Furthermore, Yin (2009) suggested the following:

In general, case studies are the preferred method when (a) 'how' and 'why' questions are being posed, $(b)$ the investigator has a little control over events and (c) the focus is on a contemporary phenomenon within a real-life context. 
Data were collected through literature study and interview. Interviews were conducted with a number of informants in this study, six key informants and one additional informant recommended by key informants. Key information are as follow: Assistant to the Economy as a representation of the Governor; (2) Director General of PD Jawi as the representative of the Board of Directors of PD Jawi; (3) Chairman of Commission III of the Regional People's Representative Assembly or DPRD; (4) Supervisory Board PD Jawi; (5) Head of the Non-Banking Bureau of Investment and $B U M D$ of the Regional Secretariat of West Java Province; (6) Head of Legislation Bureau of the Regional Secretariat of West Java Province. The additional informant is the Head of Sub-Division of the BUMD Finance of Investment Bureau Regional Secretary of West Java Province.

\section{Results and Discussion}

The results are processed through data analysis by using Hayes' theoretical dimensions.

\section{Stakeholder Management}

Hayes argued that stakeholder management efforts include the following three steps: identifying the stakeholders involved; grouping stakeholders based on their strengths and attitudes towards change and the extent of the change leaders' awareness; finally, knowing and considering their influence on change. Objectives of stakeholder management itself are determined to help the organisation's leadership understand the values desired by stakeholders. These values are formulated into the goals of change and the means to achieve them. Good stakeholder management involves all stakeholders, and thus, a proactive attitude from the organisation's leadership is required.

The study findings in this dimension reveal the following: (a) PD Jawi neither performs the three steps required in Hayes's theory nor has they ever been accomplished in a stateowned enterprise, (b) no attempt exists to map the values and wishes of stakeholders, (c) involvement of the Financial and Development Supervisory Bodies or BPKP West Java Province and the Institution of Management Padjadjaran University (known as LM-FEB Unpad), both as compilers and consultants of the Ministries of Home Affairs and Law and Human Rights, are not as stakeholders.

\section{Role of Leadership}

Hayes argued that leadership role in change management is demonstrated by the creation of vision, alignment of relationships related to vision and act of encouraging/inspiring people to achieve that vision. Hayes also argued that leadership is a collective process related to maintaining relationships with internal and external stakeholders. At the practical level, the role is applied in the form of good transformational and transactional leadership. Both forms have been applied to SOEs and have been proven successful in encouraging changes in the environment of SOEs.

The study findings show that PD Jawi's Board of Directors formulated the organisation's vision in the Business Plan, 'PD Jawi Toward a Limited Liability Company' in 2011. BPKP (2012) and the University of Padjadjaran (2014) recommend that the action plan be readjusted as per Governor Regulation Number 4/2012. However, both studies only functioned in that $P D$ Jawi 'has done something' not as a 'hint to do something'. The results of identification and other reviews show that PD Jawi failed to realise the two recommendations.

The findings show that the Board of Directors of PD Jawi strived to assume a leadership role by formulating a company vision for change. However, various policies, plans and actions (alignment) are not followed up by stakeholders who attempted to achieve such vision. The Board of Directors $P D$ Jawi failed to play its leadership role comprehensively. 


\section{Communication}

Theoretically, Hayes argued that communication change should focus on 'what, when, who and how' the Board of Directors communicates with stakeholders. The aim of communicating is to share the understanding of the direction of change and programme priorities, to reduce errors of assignment and uncertainty and to facilitate learning. Clampit et al. (2000) complemented Hayes's theory, recommending an 'underscore and explore' communication strategy for organisational change. The 'assert and find' strategy is a communication strategy that enables change managers to organise the change agenda and respond to the attention of employees and stakeholders.

The study results reveal the following. First, the Board of Directors communicated with employees and partner companies. However, communication undertaken informs 'organisational change policies' not 'opportunities for employees and prospects for stakeholders.' The form of communication categorised as 'tell and sell,' is less effective in facilitating a change process.

Second, poor communication is observed in the internal and external PD Jawi. In the internal environment, an unconformity (contradiction) exists between the Board of Directors and the Supervisory Board. In the external environment, an open discrepancy exists between the Investment Bureau and the BUMD with the Board of Directors. The communication situation with this external environment by Yin (2004) is referred to as 'collective mantra,' which is mutually reinforcing opinions but different from the factual scenario.

Communication strategies for organisational change are developed in the environment of state-owned enterprises through the principle of 'walk the talk,' which refers to the harmony between what is said and what is done. However, based on the findings of the above study, PD Jawi lacks the effort to develop effective communication strategies in facilitating change. This finding shows that the 'walk the talk' principle is not applied to organisational change processes.

\section{Motivation}

Theoretically, Hayes proposed motivating required changes regarding efforts to gain support and identify rejection. Kotter and Schlesinger (2008) added to Hayes' opinion as follows: people reject a change initiative because of (a) narrow-mindedness, (b) misconceptions and lack of faith, (c) assessment differences and (d) low tolerance for change.

The study results on $P D$ Jawi found existing misunderstanding and lack of trust on the part of the Board of Directors towards employees. The Board of Directors sees employees as 'objects' that can impede change and are deemed to lack capabilities. This condition led to a passive leadership that discourages employees or does not make any effort to motivate them. Conversely, the experience of change in SOEs found that motivation can be accomplished through formal or informal means. The choice of implemented steps is based on an intensive consideration of employee and stakeholder conditions.

\section{Transitional Management of Personal Attitude}

Hayes suggested that personal transition management efforts are meant to be the method in which organisational members see change as a threat or an opportunity. This view will help leaders plan and implement organisational change in ways that maximise benefits and minimise costs. Adam et al. expanded Hayes conception (in Hayes, 2010) in proposing that the management of personal transition in organisational change goes through several stages ranging from shock, denial, depression, release, proof, merging to thinking/study. Adam et al. revealed that each stage requires a time lag between notifications with the resulting emotional reaction. 
The study findings show that the management of personal attitude change is closely related to the communication aspect. As previously described, communication is only an explanation of change initiatives. Leadership communication similar to this one shows that the leadership of $P D$ Jawi has not developed any efforts related to managing the transition of personal attitudes. This fact proves that PD Jawi has made no effort to manage the transition of the personal attitudes of the stakeholders. Conversely, private transition management is necessary to identify the various attitudes arising from the stakeholders who, in the process, require an internalisation process.

\section{Intervention Ways}

Hayes argued that theoretically the most effective approach to facilitate change is to develop methods in which organisational members can help themselves. Commonly used techniques include providing advice, support, theoretical explanations, challenges and provision of information that can help stakeholders evaluate and interpret the situations they are facing.

The study findings show that changes in PD Jawi permit BPKP and LM FEB Unpad. The involvement of the two institutions fulfil the requirements of due diligence process (Pergub 4/2012), and the result is only a review and recommendation for PD Jawi to follow up on certain actions but not help an organisation prepare for changes.

The intervention conducted by $P D$ Jawi tended to approach institutional and political agencies to gain support from the Regional People's Representative Assembly (DPRD) West Java Province. This approach is an ineffective method of intervention for change because it fails to encourage organisation members to help themselves. This fact shows that $P D$ Jawi failed to make adequate efforts in developing the change intervention. This finding is different from the experience of PT. Garuda Indonesia, PT. Dahana and PT. Cement Indonesia, whose organisational changes are assisted by outsiders (consultants) and implemented intensively by company management.

\section{Conclusions and Recommendations}

The analysis results reveal the following. First, the slowness of business process changes; $P D$ Jawi caused less optimal management, and PD Jawi managed the problem of people per person (people's issues). Second, successful changes in business organisation are closely related to leadership role factors, communication strategies, stakeholder management, motivation, development of change interventions and management of the transition of stakeholders' personal attitudes. Third, the six factors are closely and continuously linked to one another. Each factor follows a path and is iterative in the process. The linkage between these factors is not addressed in the Hayes generic model. This study suggests the concept of interrelationship among factors as a model of change in state-owned enterprises, as illustrated below: 


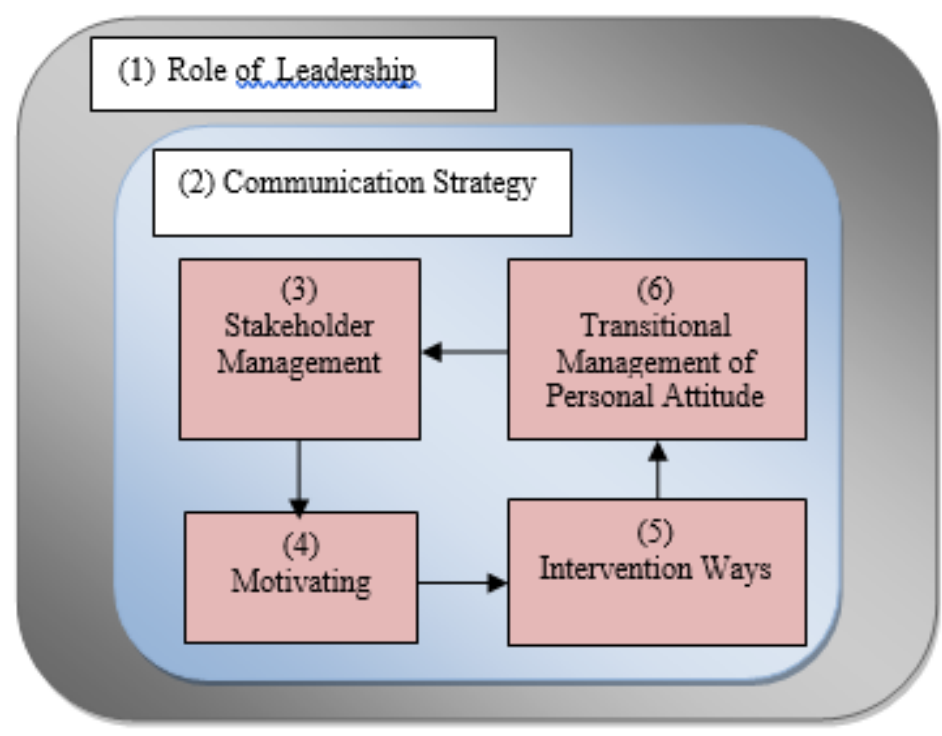

\section{Figure 4. Model for Managing Change in Government-Owned Enterprise}

\section{References}

[1] J. Hayes, "The Theory and Practice of Change Management", Third Edition, Palgrave Macmillan, New York, (2010).

[2] G. Jones, "Organizational Theory, Design and Change", Sixth Edition, Pearson, New Jersey, (2010).

[3] J. P. Kotter, "Leading Change", Harvard Business School Press.Boston, (1996).

[4] J. P. Kotter and D. S. Cohen, "The Heart of Change", Harvard Business School Press, Boston, (2002).

[5] K. Locke, "Grounded Theory in Management Research", SAGE Publications London, (2001).

[6] A. Strauss and J. Corbin, "Basic Qualitative Research: Grounded theory procedures and techniques", Sage Publications, Inc. Newbury Park, California, (1990).

[7] R. K. Yin, "Case study research: design and methods", (3 $3^{\text {rd }}$ ed). Sage Publications, Inc., Thousand Oaks, California, (2003).

[8] R. K. Yin, "Case Study Research: Design and Methods (4 $4^{\text {th }}$ ed)", Sage Publications.Inc., Thousand Oaks, California, (2009).

[9] P. G. Clampitt, R. J. DeKoch and T. Cashman, "A strategy for communicating about uncertainty", The Academy of Management Executive, vol. 14, no. 4, (2000), pp. 41-57.

[10] J. P. Kotter, "Leading Change: Why Transformation Efforts Fail", Harvard Business Review, (1995) March-April, pp. 1-10.

[11] J. P. Kotter, "What Leaders Really Do", Harvard Business Review, (1990) May-June, pp. 1-11.

[12] J. P. Kotter and A. Leonard, "Schlesinger Choosing Strategies for Change", Harvard Business Review, (2008) July-August, Reproduce October 2013 pp 1-10.

[13] J. P. Kotter, “Accelerate!”, Harvard Business Review, vol. 90, no. 4, (2012) November, pp. 45-58.

[14] Peraturan Gubernur Jawa Barat Nomor 4 Tahun 2012 tentang Tata Cara dan Mekanisme Perubahan Bentuk Hukum Perusahaan Daerah Jasa dan Kepariwisataan Provinsi Jawa Barat. Bandung, (2012).

[15] BPKP Perwakilan Provinsi Jawa Barat, "Laporan Hasil Kajian Atas Rencana Perubahan Bentuk Hukum Perusahaan Daerah Jasa dan Kepariwisataan Provinsi Jawa Barat menjadi Perseroan Terbatas”, Bandung, (2012).

[16] Business Plan PD. Jawi 2012 - 2016. Bandung (2011)

[17] Komite Nasional Kebijakan Governance (KNKG). 2006. Pedoman Umum Good Corporate Governance Indonesia. Jakarta, (2006).

[18] LMFEB-Unpad, Kajian Perubahan Bentuk Badan Hukum Perusahaan Daerah Jasa dan Kepariwisataan Provinsi Jawa Barat menjadi Perseroan Terbatas. Bandung, (2014).

[19] T. Creasey, "Defining change management: Helping others understand change management in relation to project management and organizational change", Accessed http://www.change-management.com/ProsciDefining-Change-Management.pdf [16/10/2015], (2007).

[20] H. Heriswan, 2015. 4 Langkah Transformasi Dahana. Accessed <http://swa.co.id/businessstrategy/empat-langkah-transformasi-pt-dahana> [25/3/2015]

[21] K. Lewin, "Frontiers in Group Dynamics: Concept, Method and Reality in Social Science; Social Equilibria and Social Change", Accessed http://journals.sagepub.com/doi/abs/10.1177/ 001872674700100103? journalCode=human [29/07/2013], (1947). 
International Journal of $u-$ and e- Service, Science and Technology

Vol.10, No.11 (2017)

[22] Prionomurti, Sunardi. 2015. 4 Tahap Transformasi Semen Gresik. Accessed <http://swa.co.id/businessstrategy/empat-tahap-transformasi-semen-indonesia> [25/3/2015]

[23] Satar, Emirsyah. 2014. Trust Kunci Sukses Garuda Indonesia Dari One Dollar Company Menjadi Billion Dollar Company. Accessed <http://swa.co.id/ceo-interview/trust-kunci-sukses-garuda-indonesia-darione-dollar-company-menjadi-billion-dollars-company> [25/3/2015]

[24] Satar, Emirsyah. 2013. Pemimpin Harus Punya Visi dan Menjadi Motivator. Accessed <http://swa.co.id/ceo-interview/emirsyah-satar-pemimpin-harus-punya-visi-dan-menjadi-motivator > $[25 / 3 / 2015]$ 